\title{
Rural entrepreneurial ecosystems: A systematic literature review for advancing conceptualisation
}

\author{
Evelyn Calispa Aguilar
}

\section{A B S T R A C T}

Objective: The objective of the article is to identify the specific contextual factors and mechanisms that are important for the functioning of entrepreneurial ecosystems in rural areas.

Research Design \& Methods: Qualitative analysis of 70 high-quality articles which results from a systematic literature review.

Findings: Rural poverty, natural resources endowment, peripheral location, and rural cultural values are important features of rurality which influences entrepreneurial ecosystems' performance in several ways.

Implications \& Recommendations: Features of rurality are yet to be embedded into current general entrepreneurial ecosystem frameworks as they have the potential to enhance models' capacity to capture local aspects when employed to understand and measure entrepreneurship in rural contexts.

Contribution \& Value Added: This study makes an important contribution by identifying the relevant factors and mechanisms associated with entrepreneurial ecosystems in rural contexts from the emerging literature in rural entrepreneurship.

\begin{tabular}{llll}
\hline $\begin{array}{l}\text { Article type: } \\
\text { Keywords: }\end{array}$ & research article & \\
JEL codes: & rural entrepreneurship; rural entrepreneurial ecosystem; entrepreneurial ecosystems \\
\hline \multicolumn{1}{c}{ Received: 6} & October 2020 & Revised: 4 April 2021 & Accepted: 6 May 2021 \\
\hline
\end{tabular}

\section{Suggested citation:}

Calispa Aguilar, E. (2021). Rural entrepreneurial ecosystems: A systematic literature review for advancing conceptualisation. Entrepreneurial Business and Economics Review, 9(4), 101-114. https://doi.org/10.15678/EBER.2021.090407

\section{INTRODUCTION}

Recent years have witnessed a growing academic interest in understanding the functioning of entrepreneurial (eco) systems. During the last decades, a strong emphasis has been placed on understanding the relationships between individual actors and their local socio-economic contexts, giving rise to a new concept that laid the foundations for a systemic view of entrepreneurship, known as the entrepreneurial ecosystem (EE). The term 'entrepreneurial ecosystem' is used in its broadest sense to refer to all 'those economic, social, institutional and all other important factors that interactively influence the creation, discovery, and exploitation of entrepreneurial opportunities' (Qian, Acs, \& Stough, 2013, p. 561). Entrepreneurial ecosystems research departs from the recognition that entrepreneurship can only be understood as the result of the dynamic interaction of individual factors and the local-global environmental context. In this vein, we recently observe a rapid rise in the number of academic articles about EE published in influential databases (Alvedalen \& Boschma, 2017; Cavallo, Ghezzi, \& Balocco, 2019; Malecki, 2018). However, although extensive research has been carried out, problems regarding the ecosystem's conceptualisation must still be addressed.

The main issue for the ecosystem's conceptualisation is that scholars derive their interpretations of EE from an overly narrow definition of entrepreneurship. Due to the promising effects of productive entrepreneurship in economic growth observed in some places with strong entrepreneurial ecosystems, 
researchers and policymakers intensively try to emulate such system structures elsewhere. This overexclusive approach has led to the emergence of a 'decontextualized body of literature' on entrepreneurship (Welter, Baker, \& Wirsching, 2019). Consequently, entrepreneurial ecosystems are conceptualized and operationalized in a way they can support and be conducive for a kind of entrepreneurship like that in outstanding locations such as Silicon Valley, Route 128, or Israel. This narrow conceptualisation has implications in practice as well as it leads to policymakers' frustration when their efforts in trying to build local ecosystems based on well-known successful ecosystems' structures fail (Isenberg, 2010). In the face of this situation, several prominent researchers call for the study of diversity in entrepreneurship for better theory-building based on a wider, non-discriminatory perspective on what constitutes entrepreneurship. This involves overcoming the assumption that only certain kinds of entrepreneurship can lead to wealth and job creation (Welter, Audretsch, \& Gartner, 2016). Scholars must rethink entrepreneurship, placing context at the heart of the EE concept.

The applicability of $\mathrm{EE}$ frameworks to examine every kind of ecosystem remains debatable. Current configurations of EE's components and assumed systemic conditions - interactions among pillars probably cannot accurately pinpoint the relevant aspects of entrepreneurship when employed in contexts of rural or predominantly rural locations. Although at different scales and ratios, most countries and regions are composed of a combination of urban and rural settings, and entrepreneurship happens in both. However, there are differences in the geographical, social, economic, and developmental state of urban and rural locations. The specificities location are likely to influence entrepreneurial dynamics. Therefore, in this study, I argue that there are spatial specificities from rurality, which can cause EEs to function fundamentally differently from those in urban areas. This issue has not been broadly explored in previous research.

This article conveys a systematic review of 70 high-quality articles to identify the specific contextual factors and mechanisms important for developing EEs in rural areas. The study seeks to answer the following research questions: What are the most relevant factors for entrepreneurship in rural locations? To what extent are specific spatial components from rurality integrated in current EEs' frameworks? The first section of the text provides a brief overview of the state of research in the conceptualisation of entrepreneurial ecosystems. The next section explains the research methodology employed for conducting this systematic review. Then, I discuss the results, and I conclude in the last section.

\section{LITERATURE REVIEW}

Van de Ven (1993) and Spilling (1996) pioneered a new approach to examining entrepreneurship systematically. They were among the first investigators who suggested that entrepreneurial performance of a region or locality is determined not only by the characteristics and behaviours of individual entrepreneurs, but also by the interaction of various social, economic, and political factors. They looked at entrepreneurship within a comprehensive framework to examine how these diverse actors interact to facilitate or inhibit entrepreneurial performance within a region or country. Since then, the concept of EE has become increasingly popular among researchers in the entrepreneurship field. For policymaking, the EE concept has important practical implications since it informs regional economic development strategies aiming to create supportive environments that foster innovative business (Spigel \& Harrison, 2018) and sustainable entrepreneurship (Bischoff \& Volkmann, 2018).

Despite the great academic interest, the concept of EE continues to be developed, and many fundamental conceptual, theoretical, and empirical questions remain unanswered (Kuratko, Fisher, Bloodgood, \& Hornsby, 2017; Malecki, 2018; Stam, 2015). Nevertheless, the concept of EE has already informed the development of several methods for measuring quality of EEs in practice. Each framework proposes a unique configuration of components and mechanisms within the ecosystem. For instance, the measurement framework proposed by Stangler and Bell-Masterson (2015) indicates that density, fluidity, connectivity, and diversity are four key indicators of entrepreneurial vibrancy. The Global Entrepreneurship Index and the Regional Entrepreneurship and Development Index (GEI and REDI) view entrepreneurship as the result of the 'dynamic, institutionally embedded interaction between entrepreneurial attitudes, entrepreneurial abilities, and entrepreneurial 
aspirations by individuals' (Ács, Autio, \& Szerb, 2014, p. 479). More recently, the Global Entrepreneurship Monitor (GEM) introduced the Entrepreneurial Ecosystem Quality Composite Index (ESI) diagnostic tool for measuring the quality of cities and regions entrepreneurial ecosystem based on the theoretical model of Stam (2015).

Although current EEs frameworks are very well elaborated, none of them distinguishes the 'type' of location where the index aims to be employed (apart from the national-regional distinction), thus suggesting that the frameworks are generalisable to most entrepreneurial ecosystems. Certainly, entrepreneurship exists in both urban (central) and rural (peripheral) locations, but it happens in different forms. There are contextual differences in the developmental conditions and in the levels of agglomeration of urban and rural settings which influence entrepreneurial dynamics. That is, spatial context is significant to the rural entrepreneurial process (Henderson, 2002; Müller \& Korsgaard, 2017). Surprisingly, little attention has been paid to theoretically understand such differences in the context of entrepreneurial systems. In the same vein, one critique of the literature is that current EE models remain insufficient for explaining the factors and mechanisms that affect rural entrepreneurship and thus unable to inform policies at the communal level (Muñoz \& Kimmitt, 2019).

\section{RESEARCH METHODOLOGY}

\section{Method: Systematic literature review}

For this review, I firstly formulated a clear research question following the CIMO logic (context, intervention, mechanism, outcome) developed by Denyer and Tranfield (2009). This logic serves to evaluate the inclusion or exclusion of studies. The Preferred Reporting Items for Systematic Reviews and Meta-Analyses (PRISMA) statement was used to design and document the overall process of this systematic review (Figure 1). I sought studies through the EBSCO electronic databases (Academic Search Complete, Business Source Premier, and Science Direct) and Web of Science. The search was conducted with conditions presented in Table 1 below. Keywords and synonyms for the terms were combined into 10 complex search queries, which I ran in the four databases under the same inclusion criteria, and all the records were collected. I ran the last search in May 2019.

Table 1. Inclusion criteria for screening stage

\begin{tabular}{|l|l|}
\hline Keywords & $\begin{array}{l}\text { a) 'rural AND entrepre*' } \\
\text { b) 'actor' or 'elements' or 'components or 'determinant' or 'cause' or 'factor' } \\
\text { c) 'entrep* context' or 'entrep* environment' } \\
\text { 'entrep*area' or 'entrepr*ecosystem' or 'entrepr*setting' or 'entrep* system' }\end{array}$ \\
\hline Inclusion criteria & $\begin{array}{l}\text { Language: only English } \\
\text { Years: 1975-2019 } \\
\text { Methodology: Any type, no limitation } \\
\text { Subject area: No limited } \\
\text { Type of publication: only journal articles } \\
\text { Citation number: +50; No minimum citation number for 'additional search' stage }\end{array}$ \\
\hline
\end{tabular}

Source: own study.

The initial search retrieved 20344 articles. From these, 501 records were collected based on the inclusion criteria. The exclusion of duplicates reduced this number to 248 . A total of 88 new articles were identified by manual search. A manual search using the criteria in Table 1 was conducted on 32 high-quality journals (Q1 and Q2 according to SCImago Journal Rank) in the fields of economics, econometrics, finance, economic geography, and A-type journals in regional sciences. Additional searches were conducted on 10 highly ranked journals selected from the reference list of Cavallo et al. (2019), which offers the most up-to-date review of research in EE. The first search and additional search records were merged, and duplicates were removed, giving a total of 327 articles. Based on the title and abstract examination, 224 studies were discarded for not meeting the CIMO logic criteria. The final 103 articles were categorised into three types - not relevant, relevant, and highly 
relevant - based on a critical and detailed full-text reading. To avoid unintentional bias in the selection, the categorisation I made was evaluated and approved by an external expert. Finally, only those papers categorised as 'highly relevant' $(n=70)$ were employed for the synthesis. Mendeley was employed to merge and deduplicate records. After deduplication, no specialized software was employed to manage the bibliography. Rather the process was manually performed with the support of Microsoft Excel and Word to tabulate and synthetise results.

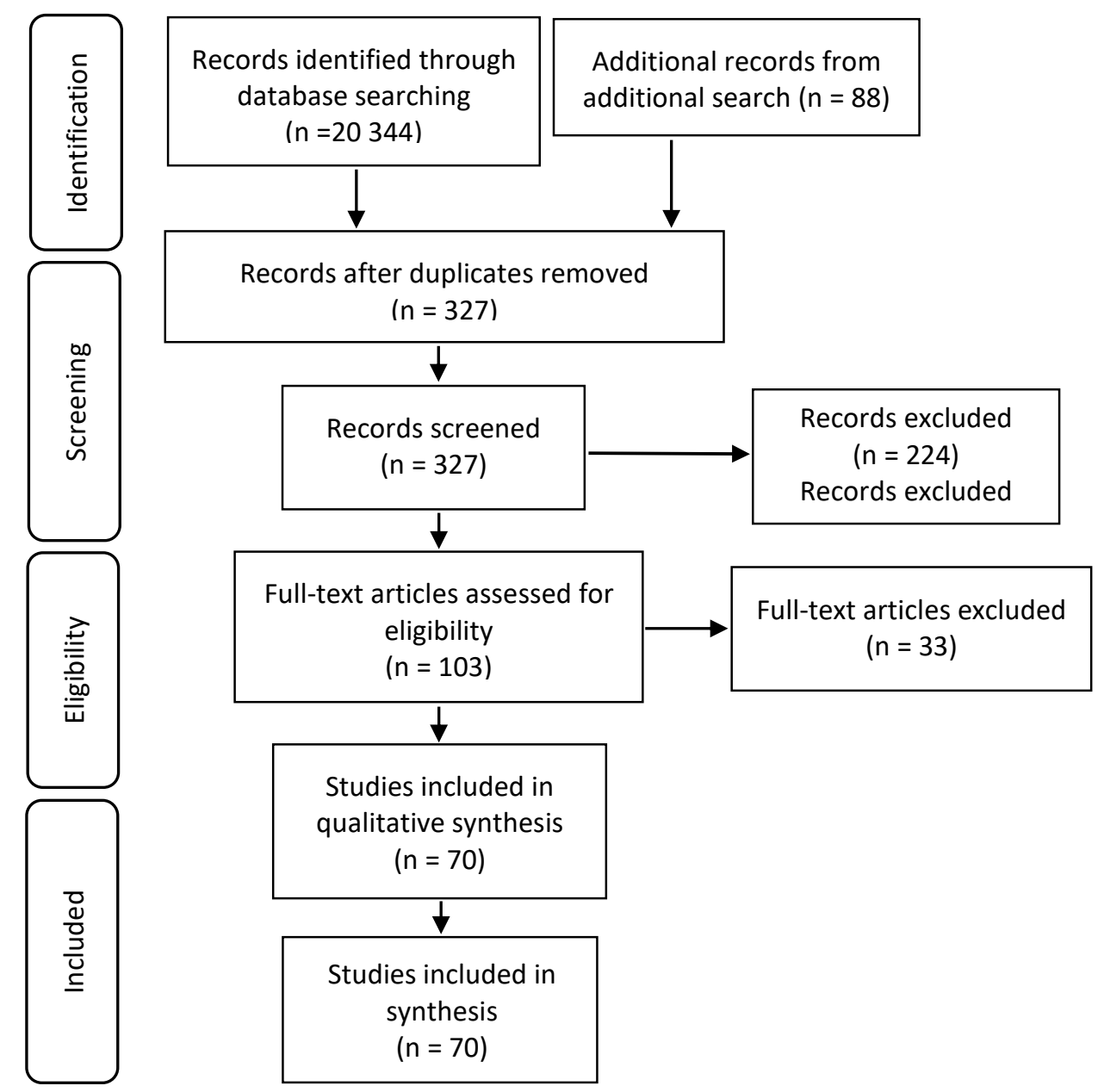

Figure 1. Preferred Reporting Items for Systematic Reviews and Meta-Analyses flow diagram Source: own elaboration.

The conceptual model

The model for EEs proposed by Stam and Van De Ven (2019) was employed as the conceptual guideline for data analysis. This well-known model provides an updated and integrative approach consisting of ten constituent elements and entrepreneurial outputs (Figure 2). The ten constructs belong to two main concepts: institutional arrangements and resource endowment. The third component of the model is the output of the entrepreneurial ecosystem, conceptualised as new value creation and represented by productive entrepreneurship. I selected an approach that is explicitly proposed as a general model of EEs. The authors of the model, Stam and Van De Ven (2019), intend their conceptual definitions to be generalisable to most entrepreneurial ecosystems.

The literature collected in this review is extensive, and the topics are scattered. Therefore, based on the focus, definitions, variables, and indicators employed in every reviewed paper, I categorised the studies according to their conceptual closeness to one or more of the ten theoretical constructs of the Stam and Van De Ven (2019) model. In this way, I determined which elements from rural literature are similar or novel to current frameworks. 


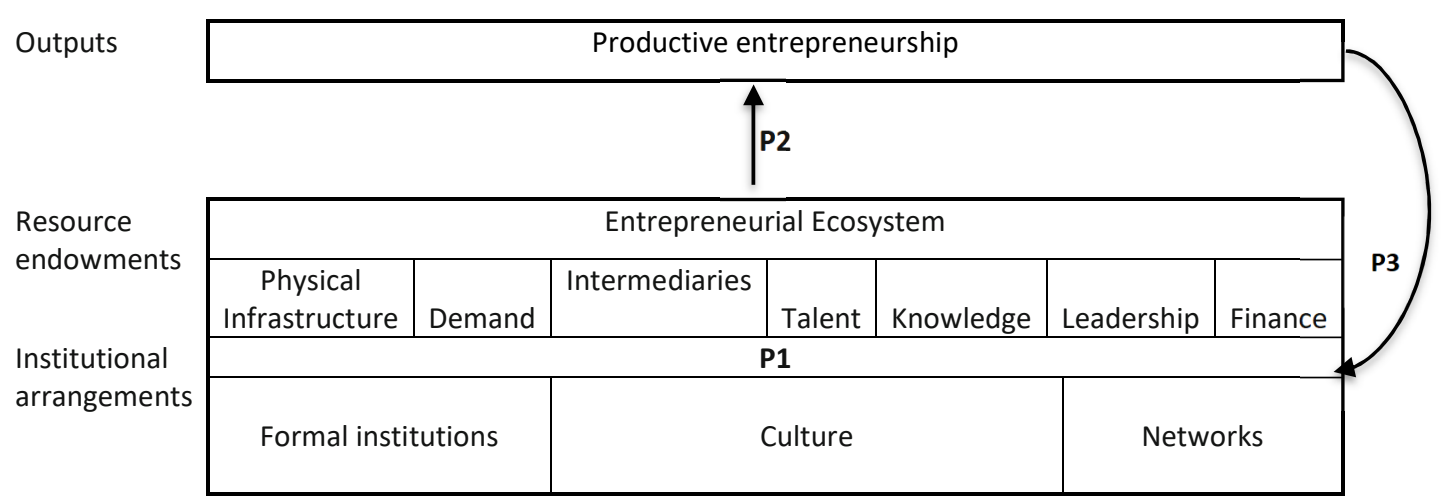

Figure 2. Elements and outputs of the entrepreneurial ecosystem Source: Stam and Van De Ven (2019).

\section{RESULTS AND DISCUSSION}

\section{The key elements and mechanisms for rural entrepreneurial ecosystems}

The main result from studies categorisation is an extended version of the constructs of entrepreneurial ecosystem elements complemented by the findings of the reviewed literature (Table 2). This synthesis stage allowed me to find two important insights. Firstly, rural literature validates the importance of both institutional and resource endowment concepts. However, some of the EE constructs seem to more attention from researchers. Most studies in this review explore formal and informal institutions, social networks, social capital, and human capital constructs while paying significantly less attention to understanding the means of consumption and services. Secondly, because they deal swith novel elements, not all 70 articles relevant for this review fit into one of the ten theoretical constructs of the model. I discuss the nature of these specific aspects in the next section.

\section{The specificities of rurality and their effect on entrepreneurship}

\section{Rural poverty}

The reviewed literature acknowledges rural poverty as a generalised concern for rural entrepreneurship in developing economies. In the shape of new business creation or economic activities diversification, entrepreneurship is mainly approached and pursued as a tool to alleviate poverty. This specific motivation has led to policymakers' pro-entrepreneurship initiatives such as government projects to focus entrepreneurship policy on the poorest. Therefore, the outcome of rural areas' EEs in developing contexts (rural livelihoods' sustainability and poverty reduction) can be different from the generally expected outcome of the systems in other contexts (value creation, job, and wealth creation). Furthermore, poverty shapes attitudes toward entrepreneurship. In deprivation circumstances, people's decisions for start-up involvement are above all influenced by the possibility of gaining a reasonable income (George et al., 2016).

Financial constraints (insufficient funds) play an important role in shaping entrepreneurship patterns. Wealthier households are more likely to start and invest in businesses as they face fewer financial limitations (Paulson \& Townsend, 2004), whereas those lacking sufficient funds turn to microfinance. Thirdly, the effects of microfinance seem to work differently for rural entrepreneurs in poor traditional contexts. Microcredit borrowing might have an indirect negative effect on the entrepreneur's overall lifestyle by increasing levels of people's worry (Bhuiyan \& Ivlevs, 2018) or reinforcing subsistence entrepreneurship, which often locks the entrepreneur in a low-level equilibrium trap (Dutta \& Banerjee, 2018). Therefore, when attempting to understand, measure, and support the development of EEs in developing economies, we must consider rural poverty as an influencing element as it can have a restricting effect on the financial resources construct. Poverty persistence in rural areas also determines the overall purchasing power of the population. Consequently, the means of consumption of poor rural areas (demand) will be different than in richer contexts. 
Table 2. Extended constructs of entrepreneurial ecosystems elements and outputs

\begin{tabular}{|c|c|c|}
\hline Concept & Constructs from rural literature & Elements \\
\hline 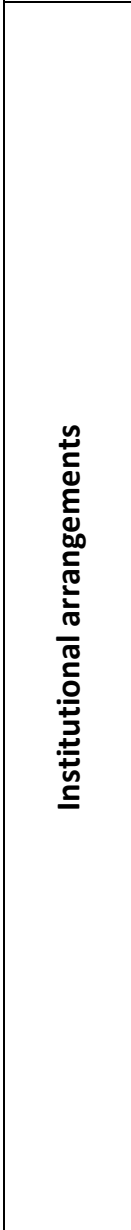 & $\begin{array}{l}\text { 1. Formal and informal institutions } \\
\text { Perceptions of the status of entrepreneurship (Basson \& Erdiaw-Kwasie, 2019) } \\
\text { Risk aversion (Cieslik \& Aoust, 2017) } \\
\text { Trust in officials and public servants (Lanjouw, Quizon, \& Sparrow, 2001) } \\
\text { The local policy approach and entrepreneurial development (Nguyen, Frederick, \& Nguyen, } \\
\text { 2014) } \\
\text { Increased support for associations (Padilla-Meléndez \& Ciruela-Lorenzo, 2018) } \\
\text { Creation of a supporting environment (Balfour, Fortunato, \& Alter, 2016) } \\
\text { Political and administrative framework (Langenbach \& Tuppen, 2017) } \\
\text { Public institutions, policymakers (Musolino, Crea, \& Marcianò, 2018) } \\
\text { Agricultural competitiveness (Pindado \& Sánchez, 2018) } \\
\text { Local entrepreneurial context (McGranahan, Wojan, \& Lambert, 2010) } \\
\text { Better developed non-farm economy (Brünjes \& Diez, 2012) } \\
\text { 2. Social Networks } \\
\text { Relationships within rural entrepreneurs (Aastard, Haugland, \& Arent, 2010; Ring, Peredo, } \\
\text { \& Chrisman, 2010) } \\
\text { Social ties (Meccheri \& Pelloni, 2006) } \\
\text { Social relationships (Zhao, Ritchie, \& Echtner, 2011) } \\
\text { Ability to collaborate with local and non-local stakeholders (Milone \& Ventura, 2018) } \\
\text { Participating in networks (Cieslik \& Aoust, 2017) } \\
\text { Village level social groups (associations) (Lanjouw et al., 2001) } \\
\text { Embeddedness in the social structure (Jack \& Anderson, 2002) } \\
\text { 'Placial embeddedness' (Korsgaard, Ferguson, \& Gaddefors, 2015) } \\
\text { Kin and personal relationships (Alsos, Carter, \& Ljunggren, 2013; George, Kotha, Parikh, } \\
\text { Alnuaimi, \& Bahaj, 2016; Peng, 2004; Venkatesh, Shaw, Sykes, Fosso Wamba, \& Macharia, } \\
\text { 2017; Yu \& Artz, 2018) } \\
\text { Isolated rural communities are likely to be rich in social capital; 'island networks' (Shantz et } \\
\text { al., 2018) } \\
\text { Collective action as productive local social capital in rural areas (Ring et al., 2010) }\end{array}$ & 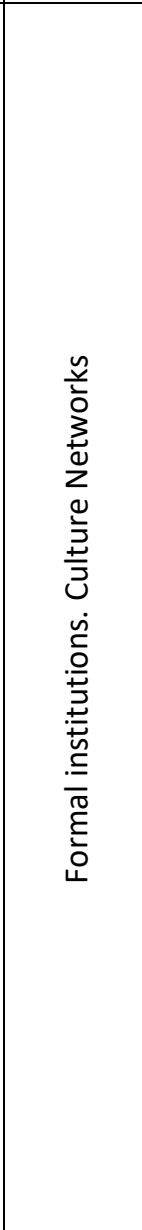 \\
\hline 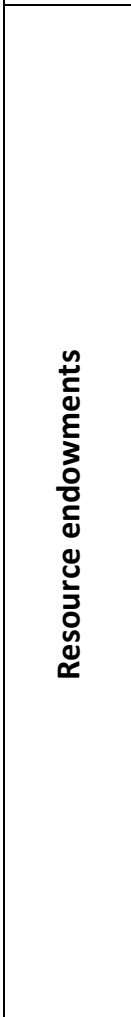 & $\begin{array}{l}\text { 1. Physical resources } \\
\text { Regional levels of urbanisation (Radicic, Bennett, \& Newton, 2017) } \\
\text { 2. Financial resources } \\
\text { Joint liability-based teams as a type of network (Chakravarty \& Shahriar, 2015) } \\
\text { Microcredit (Bhuiyan \& Ivlevs, 2018; Dutta \& Banerjee, 2018) } \\
\text { 3. Leadership } \\
\text { Entrepreneurial role models (Lafuente, Vaillant, \& Rialp, 2007) } \\
\text { Leading role models (Musolino et al., 2018) } \\
\text { The role of visionary entrepreneurs (Brooker \& Joppe, 2014) } \\
\text { The effect of legitimized 'high profile entrepreneurs' (Anderson, Warren, \& Bensemann, 2018) } \\
\text { Entrepreneurial examples -role models (Basson \& Erdiaw-Kwasie, 2019) } \\
\text { 4. Human Capital } \\
\text { Educational level (Folmer, Dutta, \& Oud, 2010) } \\
\text { Higher education and training as an efficiency enhancer for rural women entrepreneurs } \\
\text { (Nguyen et al., 2014) } \\
\text { Entrepreneurial behaviour, professional background and networks (Hassink, Hulsink, \& Grin, } \\
\text { 2016) } \\
\text { Entrepreneur's characteristics: gender, race, age, main occupation (Barbieri \& Mshenga, 2008; } \\
\text { Folmer et al., 2010; Kalantaridis, 2006; Radicic et al., 2017) } \\
\text { Language proficiency (Wei, Jiao, \& Growe, 2018) } \\
\text { Ability of entrepreneurs to respond to changes (Milone \& Ventura, 2018; Yachin, 2017) } \\
\text { Innovative behaviour (Pindado \& Sánchez, 2019) } \\
\text { Business competencies (Kasabov, 2016; Phelan \& Sharpley, 2011) } \\
\text { Entrepreneurial skills (Dias, Rodrigues, \& Ferreira, 2018) }\end{array}$ & 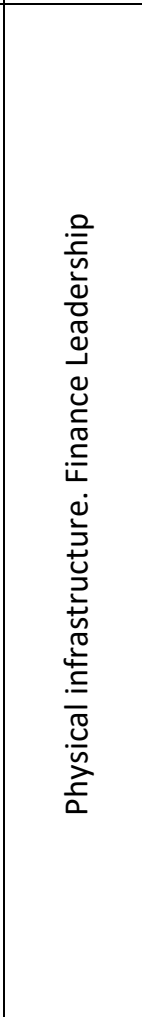 \\
\hline
\end{tabular}




\begin{tabular}{|c|c|c|}
\hline Concept & Constructs from rural literature & Elements \\
\hline 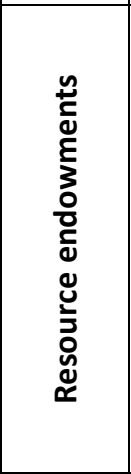 & $\begin{array}{l}\text { 5. Knowledge } \\
\text { Access to new technologies: the Internet (Cumming \& Johan, 2010) } \\
\text { Competitive environment (Freire-Gibb \& Nielsen, 2014) } \\
\text { Knowledge of the available entrepreneurial support (Malebana, 2017) } \\
\text { Farm diversification (Barbieri \& Mshenga, 2008; Basson \& Erdiaw-kwasie, 2019; Brünjes \& } \\
\text { Diez, 2012; Folmer et al., 2010; Hassink et al., 2016; Milone \& Ventura, 2018; Radicic et al., } \\
\text { 2017; Sohns \& Diez, 2017) } \\
\text { 6. Means of consumption } \\
\text { Market demand consumers' requests (Yachin, 2017) } \\
\text { 7. Producer services } \\
\text { No papers related to this element were found in this review }\end{array}$ & 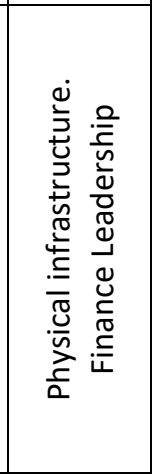 \\
\hline 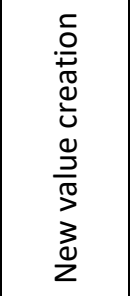 & Productive entrepreneurship & 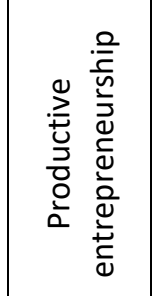 \\
\hline
\end{tabular}

Source: own study.

\section{Natural resources endowment in rural locations}

Although deprived in comparative terms, the assets' structure of rural locations offers unique entrepreneurial opportunities. Firstly, there is a role of the available natural resources in shaping the nature of rural businesses. Using the data from populations and samples, we found that businesses in rural areas are diverse, including manufacturing, farming, tourism, and trade. There is evidence that the manufacturing industry is highly shaped by locally available natural resources (e.g. vegetables, fruits, herbal plants, wood, and minerals) and locally available human resources (e.g. craftsmen, local knowledge on herbal plants use and traditional medicine or brewery). For entrepreneurs in rural areas, developing ventures based on uniquely locally available resources may be the most advantageous strategy and, indeed, may lead to distinct competitive advantages and value adding to traditional products. Such advantages are inherently difficult or impossible to replicate in other spatial settings (Dinis, 2007; Müller \& Korsgaard, 2017).

Besides, even though small towns may not have some of the advantages of large urban centres' entrepreneurial systems, there have other ecosystem elements that may compensate for these deficiencies (Roundy, 2017). Despite lacking certain resources, peripheral locations can also provide unique environments in which business start-ups and quality lifestyle can be balanced easier than in urban contexts. This feature of rurality seems to be fostering 'lifestyle-oriented' entrepreneurship in rural areas. Lifestyle entrepreneurs are understood as those individuals who run businesses in rural areas and are primarily motivated by the favourable environmental characteristics of rural areas for everyday life. Peripheral locations provide an optimal environment in which the ease of doing business and quality of life can be more easily achieved compared to urban areas (Abreu et al., 2018). Peripheral contexts can also provide spaces that stimulate moments of thinking and transformative learning, leading to creativity and innovation (Rae, 2017). More recent works on this topic focus on the potential of attracting 'creative classes' to rural areas. This approach is underpinned by the premise that the creative class - people specialising in producing new goods or designs that are broadly useful - are highly sensitive to spatial and environmental attributes (Florida, 2002). In the same line, a trend of entrepreneurs aiming at a 'slow but steady growth' is growing in rural locations. 'Exporting' and 'ambition to internationalise' are not notorious aspirations among rural entrepreneurs. Rural entrepreneurs want their business to primarily suit their lifestyle and, thus, they would rather keep their 
business simple than have it grow too big (Bensemann \& Hall, 2010). Similarly, Smith (2017) shows that rural and urban entrepreneurs may have differing entrepreneurial modes of operation. 'Making slowmoney' appears to be a common practice among village entrepreneurs. They prefer to make their wealth slowly over a lifetime by hard work and not necessarily by taking important risks.

Much literature in this review emphasises the active role of in-migrants on the creation of new ventures in the host location. Particularly, return migration can help to revitalise rural economies and alleviate poverty (Akgün, Baycan-Levent, Nijkamp, \& Poot, 2011; Démurger \& Xu, 2011). Repatriated capital is a key driving factor for promoting rural entrepreneurial development. Arrivals of entrepreneurs not only enhance economic development but also can directly contribute to compensating for the current out-migratory direction of young productive individuals (Kalantaridis \& Bika, 2006). Migrants can bring innovative ideas, connections to networks outside the local community, and different perspectives on thinking about local economic development, new start-ups, and entrepreneurship (Deller et al., 2019). However, the incorporation of advantageous resources and creativity assets into the local economy depends on the provision of a supportive local entrepreneurial context. Creative workers certainly demonstrate strong preferences for various outdoor amenities, and these preferences affect the location of talent, but this effect is highly dependent on a supporting entrepreneurial environment. To realise the positive effects of creative class attraction to rural areas and sustain robust growth in the periphery, locations require an 'effective growth trifecta' among outdoor amenities, creative class, and entrepreneurial context (McGranahan et al., 2010). Providing a supportive environment for growth must be a precondition for inviting creative entrepreneurs.

\section{Peripheral location}

Regardless of distance, rurality implies a distance to urban centres. A peripheral location entails not only geographical isolation but also marginal participation in social, cultural, political, economic, and intellectual issues (Rae, 2017). In its many forms, isolation is a key barrier to entrepreneurial opportunity and business success not only by hindering access to material resources and markets (Sohns \& Diez, 2017) but also to information about products and services. In the context of isolation, the success and failure of rural entrepreneurs depends on structural (highway proximity, mobility infrastructure) and interpersonal factors (travel choices, information sources; Gallardo \& Scammahorn, 2011; Uparna \& Weber, 2016). Since rural areas are more likely to face these challenges, recognizing this location difference can help rural communities better design and implement their entrepreneurial systems. In this regard, we argue that the urban-rural typology of the region, measured by the distance of an area from urban centres, could be integrated as an important spatial construct of the current EE structure.

\section{Rural cultural values}

How people interact in rural areas differs from how people interact in urban areas. Literature shows that the rural origin of entrepreneurs, their ethnic and cultural diversity, along with gender (women's roles), influence business creation and survival in rural areas. The rural origin and identity of an entrepreneur influence the likelihood of rural entrepreneurship. Involvement in entrepreneurship from young people in rural areas is demonstrated to be highly influenced by family tradition on entrepreneurship and business (North \& Smallbone, 2006; Yu \& Artz, 2018). Against the current tendency of young educated people migrating from rural areas looking for job opportunities, some observe that rural areas give rise to innovative entrepreneurs who are 'contravening the basic tenets of the modernisation script' (Milone \& Ventura, 2018, p. 1). Young entrepreneurs are increasingly motivated to stay in the rural areas and make their contribution to rural life by creating and developing land-based rural business, often very small (Milone \& Ventura, 2018). Similarly, the sense of belonging to a rural community can positively influence intentions even from those born non-locally. Nordb $\varnothing$ (2013) argues that second-home owners could help to build a critical mass of rural entrepreneurship and innovation as they demonstrate in different ways the interest and willingness to use their knowledge and competence to contribute to the development of their second-home community and, thus, the local economy. 
Another culture-related feature that can enable or inhibit the development of entrepreneurship is ethnic diversity. In countries such as Bolivia, where approximately $60 \%$ of the population is indigenous (Aymara, Quechua), the indigenous-non-indigenous (mestizo) dynamics can play a significant role in entrepreneurship development (Padilla-Meléndez \& Ciruela-Lorenzo, 2018). Indigenous-based entrepreneurship has its owns actors, institutions, and favourable and adverse mechanisms (Shantz et al., 2018; Widjojo \& Gunawan, 2019).

Especially women roles have a great and complex influence on entrepreneurship in rural contexts. Basically, there is a generalized agreement about the disadvantaged position of rural women entrepreneurs linked to the society in which they live. Aiming to become entrepreneurs or already in the field, women are still influenced by societal prejudice such as societal expectations of women, gender inequality, financial limitations, and limited entrepreneurship educational opportunities. Evidence from the rural tourism sector demonstrates that a gendered ideology persists within copreneurial relationships in rural tourism. The term corpeneurship is understood as activities of married couples in business (Bensemann \& Hall, 2010). In the case of indigenous women entrepreneurs in South America, the literature still evidences a dependency syndrome, which means that indigenous women are overpowered by male stereotypes (Padilla-Meléndez \& Ciruela-Lorenzo, 2018). Therefore, mechanisms like cooperative entrepreneurship and sisterhood among female entrepreneurs provide an environment for repeated affective experience that inspire women (Katre, 2018). Overall, these results reflect those of Malecki (2018) who suggests that EEs may not be genderblind and seem to be insufficiently supportive of female entrepreneurs.

\section{CONCLUSIONS}

Due to the complex attributes of entrepreneurship, current research in this field has strongly focuses on studying diversity with a view of developing more nuanced and sophisticated theories. However, EE models retain a major conceptual flaw in this regard: current approaches intrinsically assume that the factors identified as relevant for some ecosystems are equally relevant for ecosystems in other locations. Suggestions of a system with a fixed structure and composition diminish the importance of the local spatial context in which entrepreneurship actually happens. For instance, ecosystems in rural and predominantly rural areas are largely overlooked by researchers. This study argues that there are contextual factors associated with rurality that affect the functioning of entrepreneurial ecosystems. Therefore, these factors should be integrated into the current conceptualisation of EEs to improve the theory's applicability to rural contexts.

This study aimed to review the emerging literature in rural entrepreneurship and to identify the relevant factors and mechanisms important for developing EEs in rural areas. One of the more significant findings is that there is no specific structure of rural ecosystems for entrepreneurship. Rather, entrepreneurial ecosystems in rural areas consist mostly of the same structural factors from general EEs structure, but there are four specificities of rurality affecting entrepreneurial ecosystems that are novel to the current frameworks: rural poverty, natural resources endowment, peripheral location, and rural cultural values. Poverty persistence is particularly evident in rural areas of developing countries and it has a negative effect on financial capacity of entrepreneurs and the local population's means of consumption. Moreover, in poor peripheral locations the expected outcome of entrepreneurial systems is oriented to poverty alleviation and local development rather than to productive entrepreneurship itself.

Secondly, although rurality poses major challenges for entrepreneurship due to low levels of agglomeration, rural settings also offer some unique opportunities to compensate for these deficiencies by taking advantage of the availability of unique natural and human resources. Local natural resources enable specific business opportunities and foster possibilities for attracting creative entrepreneurs.

Thirdly, rural areas are geographically isolated from bigger populated areas and markets, and this condition of isolation implies not only remoteness but also marginal participation in social, cultural, 
economic, political, and intellectual life. Therefore, rurality poses certain specific challenges to business start-ups that are different from central, urban locations.

Fourthly, specific rural values - namely the rural origin of the entrepreneur, the ethnic diversity of the population, and gender dynamics - could also facilitate or prevent business start-ups in rural locations. The conclusion of this study is in accordance with previous findings that have similarly demonstrated the current typology of general EEs offers a generalised model but contextual differences must be additionally considered when attempting to employing these models in a rural context (Miles \& Morrison, 2018). A natural progression of this work could involve exploring how these novel elements can be conceptually embedded into current entrepreneurial ecosystems as a spatial condition, and how the effect of rurality on the ecosystem performance can be statistically measured. A limitation of this study is that the sample literature was collected from four databases, therefore relevant studies published elsewhere exceed the scope of this review.

\section{REFERENCES}

Aastard, J., Haugland, S., \& Arent, G. (2010). Performance Spillover Effects in Entrepreneurial Networks: Assessing a Dyadic Theory of Social Capital. Entrepreneurship Theory and Practice, 34(5), 1003-1020. https://doi.org/10.1111/j.1540-6520.2009.00346.x

Abreu, M., Oner, O., Brouwer, A., \& Leeuwen, E. Van. (2018). Well-being effects of self-employment : A spatial inquiry. Journal of Business Venturing, November, 1-19. https://doi.org/10.1016/j.jbusvent.2018.11.001

Ács, Z., Autio, E., \& Szerb, L. (2014). National Systems of Entrepreneurship: Measurement issues and policy implications. Research Policy, 43(3), 476-494. https://doi.org/10.1016/j.respol.2013.08.016

Akgün, A.A., Baycan-levent, T., Nijkamp, P., \& Poot, J. (2011). Roles of Local and Newcomer Entrepreneurs in Rural Development: A Comparative Meta-analytic Study. Regional Studies, 45(9), 37-41. https://doi.org/10.1080/00343401003792500

Alsos, G.A., Carter, S., \& Ljunggren, E. (2013). Entrepreneurship \& Regional Development: An International Journal Kinship and business: how entrepreneurial households facilitate business growth. Entrepreneurship \& Regional Development: An International Journal, 37-41. https://doi.org/10.1080/08985626.2013.870235

Alvedalen, J., \& Boschma, R. (2017). A critical review of entrepreneurial ecosystems research: towards a future research agenda. European Planning Studies, 25(6), 887-903.

Anderson, A.R., Warren, L., \& Bensemann, J. (2018). Identity, Enactment, and Entrepreneurship Engagement in a Declining Place. Journal of Small Business Management, 00(00), 1-19. https://doi.org/10.1111/jsbm.12406

Balfour, B., Fortunato, M.W., \& Alter, T.R. (2016). The creative fire: An interactional framework for rural artsbased development. Journal of Rural Studies, 1-11. https://doi.org/10.1016/j.jrurstud.2016.11.002

Barbieri, C., \& Mshenga, P.M. (2008). The role of the firm and owner characteristics on the performance of agritourism farms. Sociologia Ruralis, 48(2), 166-183. https://doi.org/10.1111/j.1467-9523.2008.00450.x

Basson, M., \& Erdiaw-kwasie, M.O. (2019). Entrepreneurship under siege in regional communities : Evidence from Moranbah in Queensland, Australia. Journal of Rural Studies, 0-1. https://doi.org/10.1016/j.jrurstud.2019.01.011

Bensemann, J., \& Hall, C.M. (2010). Copreneurship in rural tourism: exploring women's experiences. International Journal of Gender and Entrepreneurship, 2(3). https://doi.org/10.1108/17566261011079224

Bhuiyan, M.F., \& Ivlevs, A. (2018). Micro-entrepreneurship and subjective well-being: Evidence from rural Bangladesh. Journal of Business Venturing Journal. https://doi.org/10.1016/j.jbusvent.2018.09.005

Bischoff, K., \& Volkmann, C.K. (2018). Stakeholder support for sustainable entrepreneurship - a framework of sustainable entrepreneurial ecosystems. International Journal of Entrepreneurial Venturing, 10(2), 172-201. https://doi.org/10.1504/IJEV.2018.092714

Brooker, E., \& Joppe, M. (2014). Tourism Planning \& Development Entrepreneurial Approaches to Rural Tourism in the Netherlands: Distinct Differences. Tourism Planning \& Development, 11(3), 343-353. https://doi.org/10.1080/21568316.2014.889743 
Brünjes, J., \& Diez, J. (2012). 'Recession push' and 'prosperity pull' entrepreneurship in a rural developing context. Entrepreneurship \& Regional Development: An International Journal, 25, 37-41. https://doi.org/10.1080/08985626.2012.710267

Cavallo, A., Ghezzi, A., \& Balocco, R. (2019). Entrepreneurial ecosystem research: present debates and future directions. International Entrepreneurship and Management Journal, 15(4), 1291-1321. https://doi.org/10.1007/s11365-018-0526-3

Chakravarty, S., \& Shahriar, A. (2015). Selection of Borrowing Partners in Joint Liability-Based Microcredit: Evidence from Framed Field Experiments in Bangladesh. Entrepreneurship Theory and Practice, 39(1), 129144. https://doi.org/10.1111/etap.12142

Cieslik, K., \& Aoust, O. (2017). Original Article Risky Business? Rural Entrepreneurship in Subsistence Markets: Evidence from Burundi. The European Journal of Development Research, 30(4), 693-717. https://doi.org/10.1057/s41287-017-0100-9

Cumming, D., \& Johan, S. (2010). The Differential Impact of the Internet on Spurring Regional Entrepreneurship. Entrepreneurship Theory and Practice, 24(5), 857-883.

Deller, S., Kures, M., \& Conroy, T. (2019). Rural entrepreneurship and migration. Journal of Rural Studies, 66, 30 42. https://doi.org/10.1016/j.jrurstud.2019.01.026

Démurger, S., \& Xu, H. (2011). Return Migrants: The Rise of New Entrepreneurs in Rural China. World Development, 39(10), 1847-1861. https://doi.org/10.1016/j.worlddev.2011.04.027

Denyer, D., \& Tranfield, D. (2009). Producing a Systematic Review. In D.A. Buchanan \& A. Bryman (Eds.), The Sage Handbook of Organizational Research Methods (pp. 671-689). Sage Publications.

Dias, C., Rodrigues, R., \& Ferreira, J. (2018). What 's new in the research on agricultural entrepreneurship ?. Journal of Rural Studies, November, 0-1. https://doi.org/10.1016/j.jrurstud.2018.11.003

Dinis, A. (2007). Marketing and innovation: Useful tools for competitiveness in rural and peripheral areas. European Planning Studies Publication, 14(1), 37-41. https://doi.org/10.1080/09654310500339083

Dutta, A., \& Banerjee, S. (2018). Does micro finance impede sustainable entrepreneurial initiatives among women borrowers? Evidence from rural Bangladesh. Journal of Rural Studies, 60, 70-81. https://doi.org/10.1016/j.jrurstud.2018.03.007

Florida, R. (2002). The Rise of the Creative Class. The Washington Montly. Retrieved from https://washingtonmonthly.com/magazine/may-2002/the-rise-of-the-creative-class/ on March 29, 2021.

Folmer, H., Dutta, S., \& Oud, H. (2010). Determinants of Rural Industrial Entrepreneurship of Farmers in West Bengal: A Structural Equations Approach. International Regional Science Review, 33(4), 367-396. https://doi.org/10.1177/0160017610384400

Freire-Gibb, L.C., \& Nielsen, K. (2014). Entrepreneurship Within Urban and Rural Areas: Creative People and Social Networks. Regional Studies, 48(1), 139-153. https://doi.org/10.1080/00343404.2013.808322

Gallardo, R., \& Scammahorn, R. (2011). Determinants of Innovative Versus Non-Innovative Entrepreneurs in Three Southern States. The Review of Regional Studies, 41(2,3), 103-117.

George, G., Kotha, R., Parikh, P., Alnuaimi, T., \& Bahaj, A. (2016). Social structure, reasonable gain, and entrepreneurship in Africa. Strategic Management Journal, 37(6), 1118-1131.

Hassink, J., Hulsink, W., \& Grin, J. (2016). Entrepreneurship in agriculture and healthcare : Different entry strategies of care farmers. Journal of Rural Studies, 43, 27-39. https://doi.org/10.1016/j.jrurstud.2015.11.013

Henderson, J. (2002). Building the rural economy with high-growth entrepreneurs. Economic Review, 87(Q III), 45-70.

Isenberg, D. (2010). The Big Idea: How to Start an Entrepreneurial Revolution. Retrieved from https://hbr.org/2010/06/the-big-idea-how-to-start-an-entrepreneurial-revolution on March 30, 2021.

Jack, S.L., \& Anderson, A. (2002). The effects of embeddedness on the entrepreneurial process. Journal of Business Venturing, 17(5), 467-487.

Kalantaridis, C. (2006). A study into the localization of rural businesses in five European countries A Study into the Localization of Rural Businesses in Five European Countries. European Planning Studies, 14(1), 37-41. https://doi.org/10.1080/09654310500339133

Kalantaridis, C., \& Bika, Z. (2006). In-migrant entrepreneurship in rural England: beyond local embeddedness. Entrepreneurship \& Regional Development: An International Journal, 18, 37-41. https://doi.org/10.1080/08985620500510174 
Kasabov, E. (2016). When an initiative promises more than it delivers: a multi-actor perspective of rural entrepreneurship difficulties and failure in Thailand. Entrepreneurship \& Regional Development, 5626. https://doi.org/10.1080/08985626.2016.1234650

Katre, A. (2018). Facilitating affective experiences to stimulate women's entrepreneurship in rural India. International Journal of Gender and Entrepreneurship, 10(3), 270-288. https://doi.org/10.1108/IJGE-012018-0007

Korsgaard, S., Ferguson, R., \& Gaddefors, J. (2015). The best of both worlds : how rural entrepreneurs use placial embeddedness and strategic networks to create opportunities. Entrepreneurship \& Regional Development: An International Journal, 27(9), 574-598. https://doi.org/10.1080/08985626.2015.1085100

Kuratko, D., Fisher, G., Bloodgood, J.M., \& Hornsby, J. (2017). The paradox of new venture legitimation within an entrepreneurial ecosystem. Small Business Economics, 49, 119-140. https://doi.org/10.1007/s11187-017-9870-x

Lafuente, E., Vaillant, Y., \& Rialp, J. (2007). Regional Differences in the Influence of Role Models: Comparing the Entrepreneurial Process of Rural Catalonia. Regional Studies, 41(6), 779-796. https://doi.org/10.1080/00343400601120247

Langenbach, M., \& Tuppen, J. (2017). The concept of localised outdoor sports tourist systems: its application to Ardèche in south-east France. Journal of Sport \& Tourism, 21(4), 263-286. https://doi.org/10.1080/14775085.2017.1351388

Lanjouw, P., Quizon, J., \& Sparrow, R. (2001). Non-agricultural earnings in peri-urban areas of Tanzania: evidence from household survey data. Food Policy, 26(4), 385-403. https://doi.org/10.1016/S0306-9192(01)00010-0

Malebana, M.J. (2017). Knowledge of entrepreneurial support and entrepreneurial intention in the rural provinces of South Africa. Development Southern Africa, 34(1), 74-89. https://doi.org/10.1080/0376835X.2016.1259990

Malecki, E.J. (2018). Entrepreneurship and entrepreneurial ecosystems. Geography Compass, 12(3), 1-21. https://doi.org/10.1111/gec3.12359

Mcgranahan, D., Wojan, T., \& Lambert, D.M. (2010). The rural growth trifecta: outdoor amenities, creative class and entrepreneurial context. Journal of Economic Geography, 11(3), 1-29. https://doi.org/10.1093/jeg/lbq007

Meccheri, N., \& Pelloni, G. (2006). Rural entrepreneurs and institutional assistance: an empirical study from mountainous Italy. Entrepreneurship \& Regional Development: An International Journal, 18(5), 371-392. https://doi.org/10.1080/08985620600842113

Miles, M., \& Morrison, M. (2018). An effectual leadership perspective for developing rural entrepreneurial ecosystems. Small Business Economics, 2017, 1-17.

Milone, P., \& Ventura, F. (2018). New generation farmers: Rediscovering the peasantry. Journal of Rural Studies, 65, 43-52. https://doi.org/10.1016/j.jrurstud.2018.12.009

Müller, S., \& Korsgaard, S. (2017). Resources and bridging: the role of spatial context in rural entrepreneurship. Entrepreneurship \& Regional Development, 5626(November), 0-32. https://doi.org/10.1080/08985626.2017.1402092

Muñoz, P., \& Kimmitt, J. (2019). Rural entrepreneurship in place: an integrated framework. Entrepreneurship and Regional Development, 31(9-10), 842-873. https://doi.org/10.1080/08985626.2019.1609593

Musolino, D., Crea, V., \& Marcianò, C. (2018). Being excellent entrepreneurs in highly marginal areas: the case of the agri-food sector in the province of Reggio Calabria. European Countryside, 10(1), 38-57. https://doi.org/10.2478/euco-2018-0003

Nguyen, C., Frederick, H., \& Nguyen, H. (2014). Female entrepreneurship in rural Vietnam: an exploratory study. International Journal of Gender and Entrepreneurship, 6(1, 2014), 50-67. https://doi.org/10.1108/IJGE-04-2013-0034

Nordb $\varnothing$, I. (2013). Beyond the Transfer of Capital? Second-Home Owners as Competence Brokers for Rural Entrepreneurship and Innovation. European Planning Studies, 22(8), 1641-1658. https://doi.org/10.1080/09654313.2013.784608

North, D., \& Smallbone, D. (2006). Developing entrepreneurship and enterprise in Europe's peripheral rural areas: Some issues facing policy-makers. European Planning Studies, 14(1), 41-60. https://doi.org/10.1080/09654310500339125

Padilla-Meléndez, A., \& Ciruela-Lorenzo, A. (2018). Female indigenous entrepreneurs, culture, and social capital. The case of the Quechua community of Tiquipaya (Bolivia). Women's Studies International Forum, 69(June 2017), 159-170. https://doi.org/10.1016/j.wsif.2018.05.012 
Paulson, A., \& Townsend, R. (2004). Entrepreneurship and financial constraints in Thailand. Journal of Corporate Finance, 10(2), 229-262. https://doi.org/10.1016/s0929-1199(03)00056-7

Peng, Y. (2004). Kinship networks and entrepreneurs in China's transitional economy. American Journal of Sociology, 109(5), 1045-1074. https://doi.org/10.1086/382347

Phelan, C., \& Sharpley, R. (2011). Exploring Agritourism Entrepreneurship in the UK. Tourism Planning \& Development, 8(22014), 37-41. https://doi.org/10.1080/21568316.2011.573912

Pindado, E., \& Sánchez, M. (2019). Growth-oriented new agricultural ventures: the role of entrepreneurial resources and capabilities under convergence forces. European Review of Agricultural Economics, 46(5), 800833. https://doi.org/10.1093/erae/jby039

Qian, H., Acs, Z., \& Stough, R. (2013). Regional systems of entrepreneurship: The nexus of human capital, knowledge and new firm formation. Journal of Economic Geography, 13(4), 559-587. https://doi.org/10.1093/jeg/lbs009

Radicic, D., Bennett, R., \& Newton, G. (2017). Portfolio entrepreneurship in farming: Empirical evidence from the 1881 census for England and Wales. Journal of Rural Studies, 55, $289-302$. https://doi.org/10.1016/j.jrurstud.2017.08.019

Rae, D. (2017). Entrepreneurial learning: peripherality and connectedness. International Journal of Entrepreneurial Behavior \& Research, 23(3), 486-503. https://doi.org/10.1108/IJEBR-05-2016-0132

Ring, J., Peredo, A., \& Chrisman, J. (2010). Business Networks and Economic Development in Rural Communities in the United States. Entrepreneurship Theory and Practice, 34(1), 171-195. https://doi.org/10.1111/j.15406520.2009.00307.x

Roundy, P. (2017). Journal of Entrepreneurship in Emerging Economies "Small town" entrepreneurial ecosystems: Implications for developed and emerging economies. Journal of Entrepreneurship in Emerging Economies, 9(3), https://doi.org/10.1108/JEEE-09-2016-0040

Shantz, A., Kistruckb, G., \& Zietsma, C. (2018). The opportunity not taken: The occupational identity of entrepreneurs in contexts of poverty. Journal of Business Venturing, 33(February), 416-437.

Smith, R. (2017). Examining the characteristics, philosophies, operating practices and growth strategies of village entrepreneurs. International Journal of Entrepreneurial Behavior \& Research, 23(4), 708-725. https://doi.org/10.1108/IJEBR-10-2016-0350

Sohns, F., \& Diez, J.R. (2017). Explaining micro entrepreneurship in rural Vietnam - a multilevel analysis. Small Business Economics, 50, 219-237. https://doi.org/10.1007/s11187-017-9886-2

Spigel, B., \& Harrison, R. (2018). Toward a process theory of entrepreneurial ecosystems. Strategic Entrepreneurship Journal, 12(1), 151-168. https://doi.org/10.1002/sej.1268

Spilling, O. (1996). The entrepreneurial system: On entrepreneurship in the context of a mega-event. Journal of Business Research, 36(1), 91-103.

Stam, E. (2015). Entrepreneurial Ecosystems and Regional Policy: A Sympathetic Critique. European Planning Studies, 23(9), 1759-1769. https://doi.org/10.1080/09654313.2015.1061484

Stam, E., \& van de Ven, A. (2019). Entrepreneurial ecosystem elements. Small Business Economics, June. https://doi.org/10.1007/s11187-019-00270-6

Stangler, D., \& Bell-Masterson, J. (2015). Measuring entrepreneurial ecosystem. CSSRN 2580336, March, 16.

Uparna, J., \& Weber, K. (2016). When is the next bus? Influence of mobility and infrastructure on entrepreneurship in rural India. Journal of Developmental Entrepreneurship, 21(2), 1. https://doi.org/10.1142/S108494671650014X

Van de Ven, H. (1993). The development of an infrastructure for entrepreneurship. Journal of Business Venturing, $8(3), 211-230$.

Venkatesh, V., Shaw, J., Sykes, T., Fosso Wamba, S., \& Macharia, M. (2017). Networks, technology, and entrepreneurship: a field quasi-experiment among women in rural India. Academy of Management Journal, 60(5), 1709-1740. https://doi.org/10.5465/amj.2015.0849

Wei, X., Jiao, Y., \& Growe, G. (2018). Language skills and migrant entrepreneurship: evidence from China. Small Business Economics. 53, 981-999. https://doi.org/10.1007/s11187-018-0105-6

Welter, F., Audretsch, D., \& Gartner, W. (2016). Entrepreneurship - A Call for Entrepreneurship Research to Embrace Entrepreneurial Diversity. Entrepreneurship Theory and Practice, 41(3), 1-11. https://doi.org/10.1111/etap.12258 
Welter, F., Baker, T., \& Wirsching, K. (2019). Three waves and counting: the rising tide of contextualization in entrepreneurship research. Small Business Economics, 52, 319-330. https://doi.org/10.1007/s11187-018-0094-5

Widjojo, H., \& Gunawan, S. (2019). Indigenous Tradition: An Overlooked Encompassing-Factor in Social Entrepreneurship. Journal of Social Entrepreneurship, 1-23.

Yachin, J.M. (2017). The entrepreneur-opportunity nexus: discovering the forces that promote product innovations in rural micro-tourism firms. Scandinavian Journal of Hospitality and Tourism, 0(0), 1-19.

Yu, J., Zhou, J.X., Wang, Y., \& Xi, Y. (2013). Rural Entrepreneurship in an Emerging Economy: Reading Institutional Perspectives from Entrepreneur Stories. Journal of Small Business Management, 51(2), 183-195.

Yu, L., \& Artz, G. (2018). Does rural entrepreneurship pay?. Small Business Economics. 53, 647-668. https://doi.org/10.1007/s11187-018-0073-x

Zhao, W., Ritchie, J., \& Echtner, C.M. (2011). Social capital and tourism entrepreneurship. Annals of Tourism Research, 38(4), 1570-1593. https://doi.org/10.1016/j.annals.2011.02.006

\section{Author}

\section{Evelyn Calispa Aguilar}

PhD Candidate in Regional Development at the University of Pécs, Hungary. Master in International Development from the University of Manchester, United Kingdom. Her research interests include rural development, rural entrepreneurship and tourism development.

Correspondence to: Evelyn Calispa, PhD Candidate, Faculty of Business and Economics, University of Pécs, Rákóczi út 80, 7622, Hungary, e-mail: evelyn.calispa@pte.hu

ORCID (1) http://orcid.org/0000-0002-7030-2800

\section{Acknowledgements and Financial Disclosure}

I am grateful to Dr. Éva Somogyiné Komlósi for the continuous support in preparing this manuscript. Thanks also to Prof. László Szerb for the comments and suggestions on the discussion of an earlier version of this article.

\section{Conflict of Interest}

The authors declare that the research was conducted in the absence of any commercial or financial relationships that could be construed as a potential conflict of interest.

\section{Copyright and License}

This article is published under the terms of the Creative Commons

Attribution - NoDerivs (CC BY-ND 4.0) License

http://creativecommons.org/licenses/by-nd/4.0/ 